\title{
Identification of the sex pheromone of Phyllophaga cuyabana (Coleoptera: Melolonthidae)
}

\author{
Paulo H. G. Zarbin, ${ }^{\mathrm{a}, *}$ Walter S. Leal, ${ }^{\mathrm{b}}$ Crébio J. Ávila ${ }^{\mathrm{c}}$ and Lenita J. Oliveira ${ }^{\mathrm{d}}$ \\ ${ }^{a}$ Departamento de Química, Universidade Federal do Paraná, CP 19081, CEP 81531-990, Curitiba, PR, Brazil \\ ${ }^{\mathrm{b}}$ Department of Entomology, University of California, Davis, CA 95616, USA \\ ${ }^{\mathrm{c}}$ Embrapa-CPAO, CP 661, CEP 79804-970, Dourados, MS, Brazil \\ ${ }^{\mathrm{d}}$ Embrapa-CNPSo, CP 231, CEP 86001-970, Londrina, PR, Brazil
}

Received 1 December 2006; revised 9 January 2007; accepted 15 January 2007

Available online 18 January 2007

\begin{abstract}
Phenol 1 and p-cresol 2 were identified as sex pheromone components released by females Phyllophaga cuyabana. The compounds are produced in a ratio of $1: 1$, as detected by the analysis of pheromone gland extract. In field experiments, the capture of males in traps baited with the synthetic blend were significantly higher than in control traps.

(c) 2007 Elsevier Ltd. All rights reserved.
\end{abstract}

Since 1985, a complex of white grub larvae has caused damage to soybean crops in a number of regions in Brazil. Phyllophaga cuyabana is one of the most important pests of this complex. This is a univoltine species that develops completely underground, making its control difficult by conventional methods. ${ }^{1}$ The genus Phyllophaga is mainly associated with dicotyledonous plants, and references to its occurrence on monocotyledons and gymnosperms are rare. ${ }^{2}$

Flight activity of $P$. cuyabana occurs shortly after sunset, from October to December. Adults leave the soil and fly mainly to mate, after which they return to the soil and remain buried below the surface. ${ }^{1}$ The species display a calling behavior by extruding an abdominal gland in a fashion similar to the calling of moths ${ }^{3}$ (Fig. 1a, detail).

Chemical communication in the Phyllophaga has been reported for Phyllophaga anxia, ${ }^{4}$ Phyllophaga elenans, ${ }^{5}$ Phyllophaga lancelota, ${ }^{6}$ and Phyllophaga crinita, ${ }^{7}$ and the results point to the use of phenolic, amino acid, and terpenoid compounds. ${ }^{3}$

In a preliminary laboratory and field tests, the female $P$. cuyabana gland extract showed biological activity to the males. ${ }^{8}$ So, the objective of this work was to describe the

\footnotetext{
* Corresponding author. Tel.: +55 413361 3174; fax: +55 413361

3186; e-mail: pzarbin@quimica.ufpr.br
}

identification of the female-produced sex pheromone of the species and the results of field trapping tests.

The GC profile of the crude extract from pheromone glands of $P$. cuyabana is shown in Figure 1a. Apart from the two hydrocarbons that appear as major compounds, probably of tissue origin, ${ }^{9}$ the compounds listed as $\mathbf{1}$ and 2 are the only relevant peaks present in the extract. These same peaks could be detected as female-specifics by GC analysis of volatiles collected from males and females. However, in this case, due to the alternating nocturnal activity of different individuals of the population, ${ }^{1}$ the volatiles were collected during $48 \mathrm{~h}$, and the extracts were highly contaminated by several other by-products, probably from the food stuff, that interfered and made the analysis difficult.

The mass spectra of compounds $\mathbf{1}$ and $\mathbf{2}$ matches perfectly with the fragmentation pattern of phenol and $p$-cresol, respectively (Fig. $1 \mathrm{~b}$ and c). The identity was further confirmed by co-injection with the authentic standards on both polar and nonpolar columns. Phenol 1 was described as the first sex pheromone identified for a scarab beetle, Costelytra zealandica, ${ }^{10}$ as well as the minor constituent of the pheromone of Holotrichia consanguinea.${ }^{11}$ On the other hand, this is the first time that $p$-cresol 2 is found as a semiochemical.

In field experiments, only $P$. cuyabana males were captured in traps baited with the 1:1 ratio of synthetic lures incorporated into plastic devices (ChemTica Int, Costa 

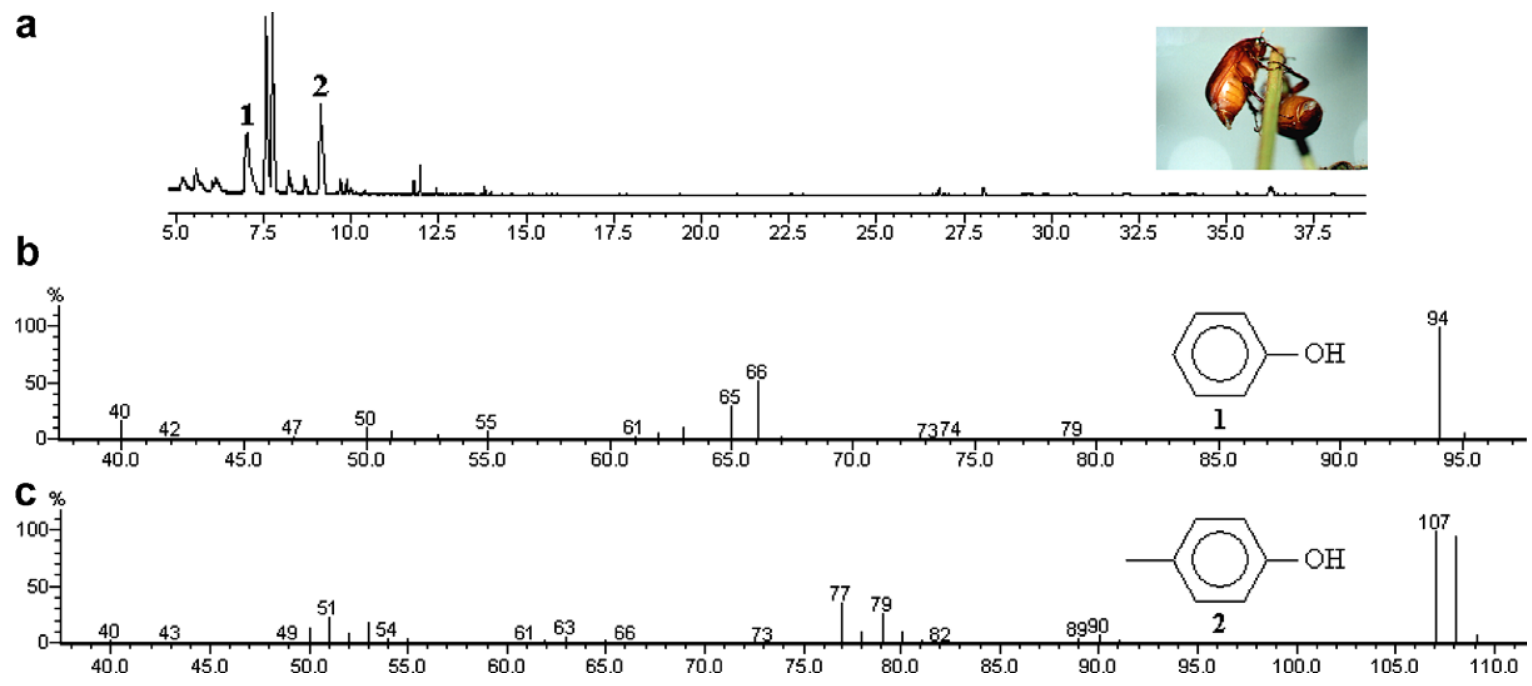

Figure 1.

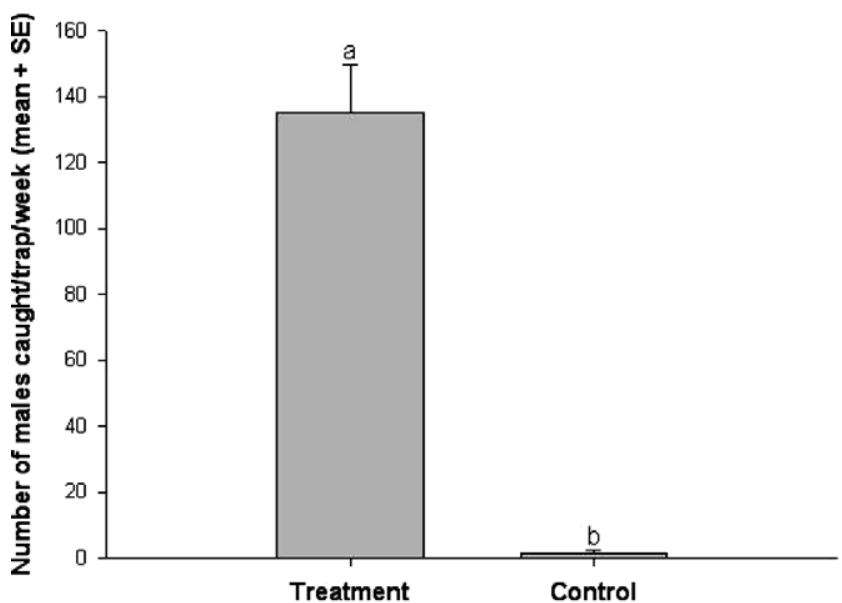

Figure 2.

Rica), indicating that phenol $\mathbf{1}$ and $p$-cresol $\mathbf{2}$ are components of the sex pheromone of the species. The capture of the treatment was significantly different from the empty trap employed as control ${ }^{12}(P<0.001)$, as shown in Figure 2, above.

In summary, we described here the identification and field evaluation of the sex pheromone of $P$. cuyabana. The results obtained suggests that the species utilizes a sex pheromone blend that can be utilized in fields for monitoring the occurrence of this agricultural pest.

\section{Acknowledgments}

This work was supported by the International Foundation for Science (Sweden), Organization for Prohibition of Chemical Weapons (Netherlands), CNPq, Fundação Araucária and Embrapa/Prodetab (Brazil).

\section{References and notes}

1. Oliveira, L. J.; Garcia, M. A. Pesq. Agropec. Bras. 2003, $38,179-186$.

2. Morón, M. A. El genero Phyllophaga em México: morfologia, distribuicion y sistemática supra-especifica (Insecta: Coleoptera); Instituto de Ecologia: México, 1986; 341p.

3. Leal, W. S. Аnпи. Rev. Entomol. 1998, 43, 39-61.

4. Zhang, A.; Robbins, P. S.; Leal, W. S.; Linn, C. E., Jr.; Villani, M. G.; Roelofs, W. L. J. Chem. Ecol. 1997, 23, 231-245.

5. Leal, W. S.; Oehlschlager, A. C.; Zarbin, P. H. G.; Hidalgo, E.; Shannon, P. J.; Murata, Y.; Gonzalez, L.; Andrade, R.; Ono, M. J. Chem. Ecol. 2003, 29, 15-25.

6. Nojima, S.; Robbins, P. S.; Salsbury, G. A.; Morris, B. D.; Roelofs, W. L.; Villani, M. G. J. Chem. Ecol. 2003, 29, 2439-2446.

7. Robbins, P. S.; Crocker, R. L.; Nojima, S.; Morris, B. D.; Roelofs, W. L.; Villani, M. G. Naturwissenschaften 2003, 90, 517-520.

8. Oliveira, L. J. Unpublished data.

9. Leal, W. S.; Zarbin, P. H. G.; Wojtasek, H.; Ferreira, J. T. Eur. J. Biochem. 1999, 259, 175-180.

10. Henzell, R. F.; Lowe, M. D. Science 1970, 168, 1005-1006.

11. Leal, W. S.; Yadava, C. P. S.; Vijayvergia, J. N. J. Chem. Ecol. 1996, 22, 1557-1566.

12. Evaluation of the candidate pheromones was conducted at the fields of the Embrapa-CPAO, in Dourados, Mato Grosso do Sul, Brazil, in October and November of 2004. Capture data were collected weekly for at least five consecutive weeks. After inspection of the traps, the data were tested for significance by ANOVA using the $\mathrm{R}$ statistical package (R Development Core Team 2005). The treatments followed by the same letter are not significantly different at $5 \%$ probability. 